\section{Preparation of 5'-Silyl-2'-Orthoester \\ Ribonucleosides for Use in Oligoribonucleotide Synthesis}

This unit describes the synthesis of chemically protected ribonucleoside monomers that can be used to prepare oligoribonucleotides using either manual or automated synthesis approaches. The protection strategy employs two orthogonal protecting groups-a fluoride ion-labile silyl ether on the 5'-hydroxyl and an acid-labile orthoester on the 2'-hydroxyl-as described by Scaringe et al. (1998). The structures of the protected phosphoramidite derivatives of the four standard ribonucleosides ( $\mathrm{rA}, \mathrm{rC}, \mathrm{rG}$, and $\mathrm{U}$ ) are shown in Figure 2.10.1. These reagents are used with appropriate modifications of standard solid-phase synthesis methods (Matteucci and Caruthers, 1981) to efficiently and rapidly assemble oligoribonucleotides.

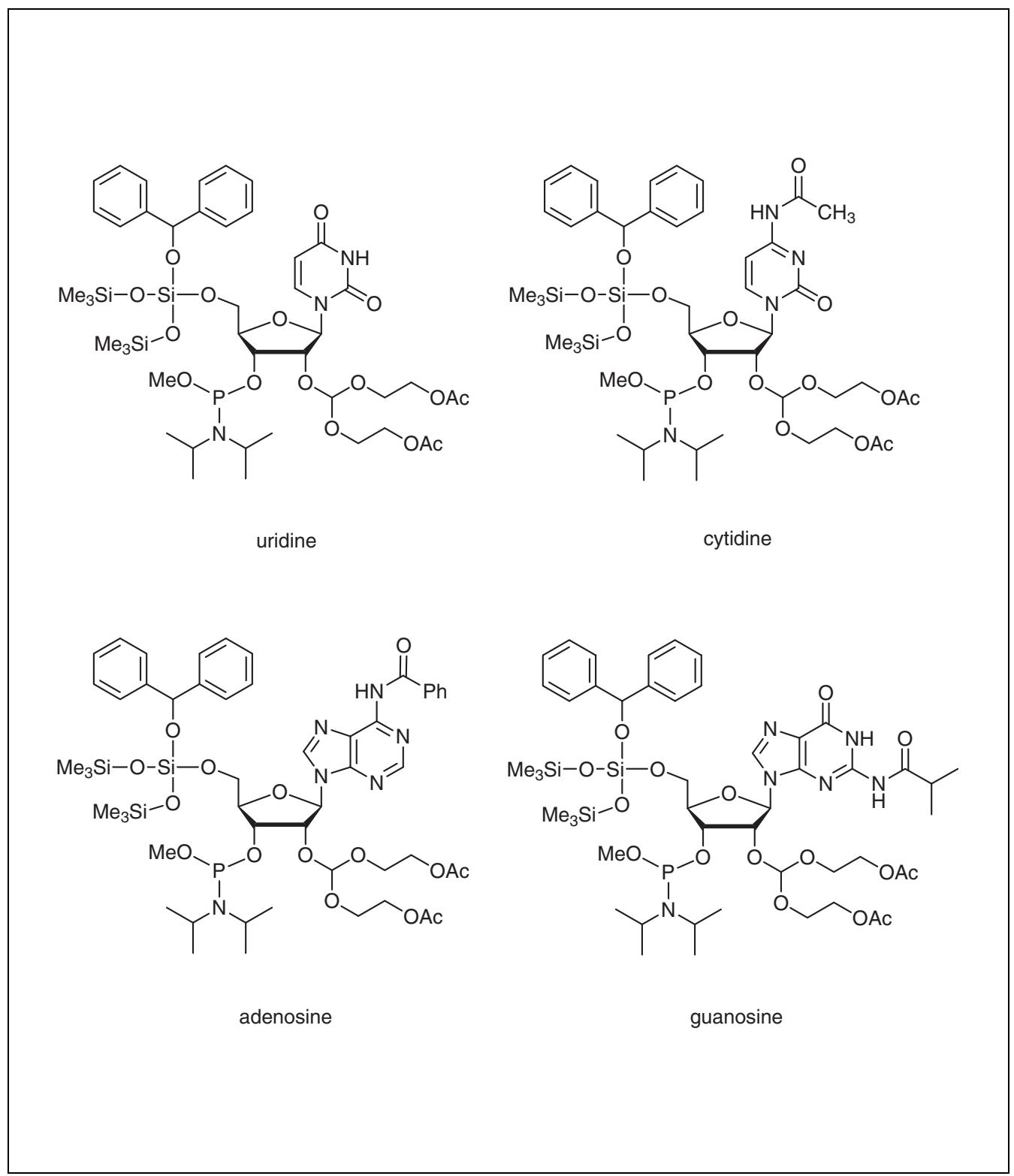

Figure 2.10.1 Protected ribonucleoside phosphoramidites for 5'-O-silyl-2'-O-orthoester RNA synthesis.

Contributed by Stephen A. Scaringe, David Kitchen, Robert J. Kaiser, and William S. Marshall

Current Protocols in Nucleic Acid Chemistry (2004) 2.10.1-2.10.16

Copyright @ 2004 by John Wiley \& Sons, Inc.
Protection of

Nucleosides for Oligonucleotide Synthesis

2.10.1

Supplement 16 
The choice of protecting groups described above is predicated on the following requirements. (1) The 2'-hydroxyl must be protected with a species that is stable to the conditions of chain assembly. (2) The synthesis procedure must protect against product cleavage from the solid support and against removal of the protecting groups on the nucleobases. (3) The protecting group must be easily removed at the end of the procedure under mildly acidic aqueous conditions. (4) Given items 1 to 3, the acid-labile 4,4'-dimethoxytrityl (DMTr) group that is traditionally used to protect the $5^{\prime}$-hydroxyl in deoxyribonucleotide synthesis must be replaced with a moiety that does not require acidic or basic conditions for its rapid removal.

The $5^{\prime}-O$-silyl ether and $2^{\prime}-O$-orthoester groups fit these criteria and have been structurally optimized to provide crude oligoribonucleotides of excellent purity and biological activity. Using commercial synthesizers, the $5^{\prime}$-O - -silyl-2'-O-orthoester chemistry enables routine synthesis of oligoribonucleotides up to 80 bases in length, regardless of sequence or secondary structure.

Synthesis of the required monomers begins from the standard base-protected ribonucleosides $\mathrm{rA}^{\mathrm{Bz}}$ (benzoyl), $\mathrm{rC}^{\mathrm{Ac}}$ (acetyl), $\mathrm{rG}^{i-\mathrm{Bu}}$ (isobutyryl), and $\mathrm{U}$ (unprotected). The procedure for synthesizing the protected uridine phosphoramidite is presented in detail (see Basic Protocol). The syntheses of the other three phosphoramidites-adenosine, guanosine, and cytidine-are essentially identical. Modifications to the purification procedures, as well as compound characterization data, are detailed below (see Alternate Protocols 1 to 3$)$.

BASIC PROTOCOL

Preparation of 5'-Silyl-2'Orthoester Ribonucleosides

2.10.2

\section{SYNTHESIS OF 2'-ACE-PROTECTED URIDINE RIBONUCLEOSIDE PHOS- PHORAMIDITE}

This protocol describes the synthesis of $5^{\prime}$ - $O$-benzhydroxy-bis(trimethylsilyloxy)silyl-2'$O$-bis(acetoxyethyloxy)methyl-3'-O-( $N, N$-diisopropylamino)methoxyphosphinyl uridine. The general strategy for preparation of the $5^{\prime}-O$-silyl-2'-O-orthoester-ribonucleoside- $3^{\prime}-O$-phosphoramidites consists of five steps: (1) simultaneous temporary protection of the $5^{\prime}$ - and $3^{\prime}$-hydroxyls, (2) conversion of the $2^{\prime}$-hydroxyl to the $2^{\prime}$-O $O$-orthoester using tris(acetoxyethyl)orthoformate (ACE orthoformate), (3) removal of the temporary $5^{\prime}$ - and 3'-hydroxyl-protecting groups, (4) regioselective introduction of the $5^{\prime}$-O-silyl-ether protecting group using benzhydroxy-bis(trimethylsilyloxy)chlorosilane $(\mathrm{BzH}-\mathrm{Cl})$, and (5) preparation of the $3^{\prime}$-O-phosphoramidite. These steps are illustrated for the uridine derivatives in Figures 2.10.2 to 2.10.6.

NOTE: All reactions must be carried out using proper ventilation (fume hood) and personal protective wear (e.g., gloves, eye protection). All reagents without specified vendors should be of the highest purity and dryness possible. Glassware for performing the synthetic transformations should be thoroughly cleaned and dried in an oven at $110^{\circ} \mathrm{C}$ for $\geq 30$ min before use.

\section{Materials}

Uridine (S.1; 244 g/mol; Monomer Sciences)

Pyridine

1,3-Dichloro-1,1,3,3-tetraisopropyldisiloxane (TIPS-Cl ${ }_{2} ; 315 \mathrm{~g} / \mathrm{mol} ; d=0.986$ $\mathrm{g} / \mathrm{mL}$; Monomer Sciences)

Toluene

Dichloromethane

$5 \%$ and $8 \%(\mathrm{w} / \mathrm{v})$ aqueous sodium bicarbonate $\left(\mathrm{NaHCO}_{3}\right)$

Saturated aqueous sodium chloride $(\mathrm{NaCl})$

Anhydrous sodium sulfate $\left(\mathrm{Na}_{2} \mathrm{SO}_{4}\right)$ 
Silica gel 60 (for column chromatography)

Hexane

Ethyl acetate (EtOAc)

Silica gel thin-layer chromatography (TLC) plates

Methanol $(\mathrm{MeOH})$

Acetonitrile $(\mathrm{MeCN})$

Tris(2-acetoxyethyl) orthoformate ( $322 \mathrm{~g} / \mathrm{mol}$; Dharmacon Inc.)

Pyridinium $p$-toluenesulfonate $(251 \mathrm{~g} / \mathrm{mol})$

Triethylamine (TEA)

4-tert-Butyldimethylsiloxy-3-penten-2-one (238 mL/mol; Silar)

$N, N, N^{\prime}, N^{\prime}$-Tetramethylethylene diamine (TEMED; $150 \mathrm{~mL} / \mathrm{mol}$ )

$48 \%$ (w/v) aqueous hydrofluoric acid (HF; $32 \mathrm{~mL} / \mathrm{mol}$ )

Diisopropylamine $(140 \mathrm{~mL} / \mathrm{mol})$

Benzhydroxy-bis(trimethylsilyloxy)chlorosilane (BzH-Cl; $425 \mathrm{~g} / \mathrm{mol}$;

Dharmacon Inc.)

Acetone

$\operatorname{Bis}(N, N$-diisopropylamino)methoxyphosphine (262 g/mol; Monomer Sciences)

$0.45 \mathrm{M} 1 H$-tetrazole in MeCN (AIC)

Ethanol (EtOH)

Rotary evaporator

1-L separatory funnel

Glass-fritted Buchner funnel (coarse porosity) and side-arm Erlenmeyer flask

High-vacuum pump

Water aspirator

$50 \times 600-$ mm chromatography column

Additional reagents and equipment for flash chromatography (APPENDIX $3 E$ ) and

TLC (APPENDIX 3D)

NOTE: For solvent evaporation on a rotary evaporator, the required vacuum source will depend on the boiling point of the solvent involved. For dichloromethane and hexane, a water aspirator or diaphragm pump will suffice. For all other solvents, a high-vacuum oil pump is needed.

NOTE: The efficiency of reactions as well as the results of column chromatography at each step are assessed by TLC on silica gel plates. It is suggested that the TLC plates be spotted in three horizontal locations at the origin of the plate as follows: (1) starting material alone, (2) co-spot of starting material plus crude reaction mixture or product fraction, and (3) crude reaction mixture or product fraction alone. In this way, the conversion of starting material to product, or the purity of the product fraction, can be conveniently monitored.

\section{Protect $3^{\prime}$ - and $5^{\prime}-\mathrm{OH}(\mathrm{S} .2)$}

1. Co-evaporate $40 \mathrm{mmol}(9.76 \mathrm{~g})$ uridine (S.1; Fig. 2.10.1) with $50 \mathrm{~mL}$ pyridine on a rotary evaporator equipped with a vacuum pump. Dissolve residue in $50 \mathrm{~mL}$ fresh pyridine and chill reaction mixture in an ice bath.

2. Add $13.86 \mathrm{~mL}$ (44 mmol; 1.1 equiv per equiv uridine) TIPS- $\mathrm{Cl}_{2}$ dropwise over 60 min to the stirred, cold uridine solution. Remove ice bath and stir solution at room temperature for an additional $30 \mathrm{~min}$. Add $2 \mathrm{~mL}$ water to quench the reaction.

3. Remove pyridine on the rotary evaporator, and then co-evaporate the residue once with $100 \mathrm{~mL}$ toluene to remove as much pyridine as possible.

Protection of

Nucleosides for Oligonucleotide Synthesis

2.10 .3 
4. Add $300 \mathrm{~mL}$ dichloromethane to the residue and swirl to dissolve. Transfer the solution to a 1-L separatory funnel and wash once with $300 \mathrm{~mL}$ of $5 \%$ aqueous $\mathrm{NaHCO}_{3}$.

5. Separate the layers and wash the aqueous phase with an additional $150 \mathrm{~mL}$ dichloromethane.

6. Combine the dichloromethane extracts and wash once with $200 \mathrm{~mL}$ saturated aqueous $\mathrm{NaCl}$.

7. Wash the $\mathrm{NaCl}$ solution with $50 \mathrm{~mL}$ dichloromethane.

8. Combine the dichloromethane extracts and dry over $50 \mathrm{~g}$ anhydrous $\mathrm{Na}_{2} \mathrm{SO}_{4}$. Remove the solid by vacuum filtration using a glass-fritted Buchner funnel (coarse porosity) and a side-arm Erlenmeyer flask.

9. Remove the dichloromethane on the rotary evaporator, and then co-evaporate the residue once with $100 \mathrm{~mL}$ toluene to remove any remaining pyridine. Dry the crude product under high vacuum (with a high-vacuum pump) for $1 \mathrm{hr}$.

10. Prepare a flash chromatography (APPENDIX 3E) column using $250 \mathrm{~g}$ silica gel 60 in a $50 \times 600-\mathrm{mm}$ chromatography column and a 50:50 (v/v) hexane/EtOAc solvent system.

11. Dissolve the dry product in $50 \mathrm{~mL}$ of 50:50 hexane/EtOAc and load onto the column. Elute with the same solvent system (typically $2 \mathrm{~L}$ ). Collect $20-\mathrm{mL}$ fractions and monitor the results of the separation by TLC (APPENDIX $3 D$ ) on silica gel plates in $6 \%$ (v/v) $\mathrm{MeOH} / \mathrm{CH}_{2} \mathrm{Cl}_{2}$. Visualize TLC separation using UV light.

The product has an $R_{f}$ of 0.5 under these conditions.

12. Pool the fractions containing pure product and evaporate to dryness on the rotary evaporator to obtain a white crystalline powder.

The molecular weight of $3^{\prime}, 5^{\prime}$-O-TIPS-uridine (S.2; Fig. 2.10.2) is $486 \mathrm{~g} / \mathrm{mol}$. The yield is $15.57 \mathrm{~g}(80 \%) .{ }^{1} \mathrm{H} \mathrm{NMR}\left(\mathrm{CDCl}_{3}\right): \delta 10.41(\mathrm{~b}, 1 \mathrm{H}), 7.81(\mathrm{~d}, \mathrm{~J}=8.4 \mathrm{~Hz}, 1 \mathrm{H}), 5.72-5.69(\mathrm{~m}$, $1 \mathrm{H}), 5.66(\mathrm{~d}, \mathrm{~J}=8.4 \mathrm{~Hz}, 1 \mathrm{H}), 4.38(\mathrm{~b}, 1 \mathrm{H}), 4.23-4.18(\mathrm{~m}, 4 \mathrm{H}), 3.96(\mathrm{~d}, \mathrm{~J}=12.8 \mathrm{~Hz}, 1 \mathrm{H})$, 1.05-0.90 $(\mathrm{m}, 28 \mathrm{H}) .{ }^{13} \mathrm{CNMR}\left(\mathrm{CDCl}_{3}\right): \delta$ 164.0, 150.7, 139.9, 102.1, 91.1, 81.8, 75.1, 68.4, 60.0, 17.6, 17.5, 17.4, 17.3, 17.1, 17.02, 17.01, 16.9, 13.4, 13.1, 13.0, 12.5. Exact mass calculated for $\mathrm{C}_{21} \mathrm{H}_{38} \mathrm{~N}_{2} \mathrm{O}_{7} \mathrm{Si}_{2}: 486.2$; found by $\operatorname{ESMS}(\mathrm{M}+\mathrm{H}): 487$.

Preparation of 5'-Silyl-2'Orthoester

Ribonucleosides

2.10.4

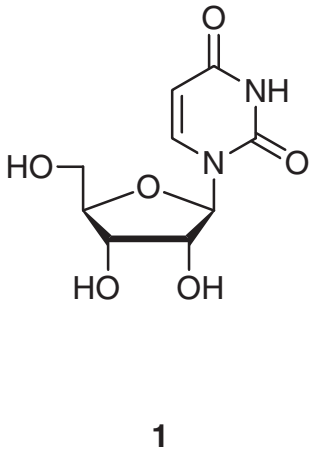

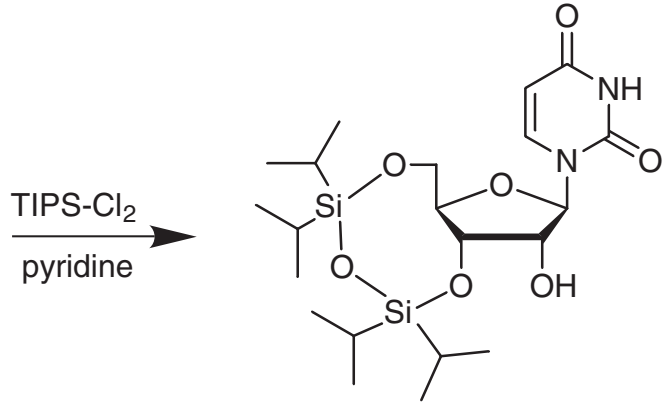

2

Figure 2.10.2 $3^{\prime}, 5^{\prime}$-Protection of the nucleoside. Synthesis of $3^{\prime}, 5^{\prime}-O$-(tetraisopropyldisiloxane1,3-diyl)uridine from uridine. TIPS- $\mathrm{Cl}_{2}, 1,3$-dichloro-1,1,3,3-tetraisopropyldisiloxane. 


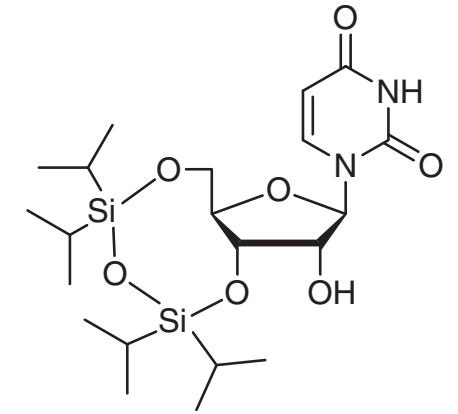

2

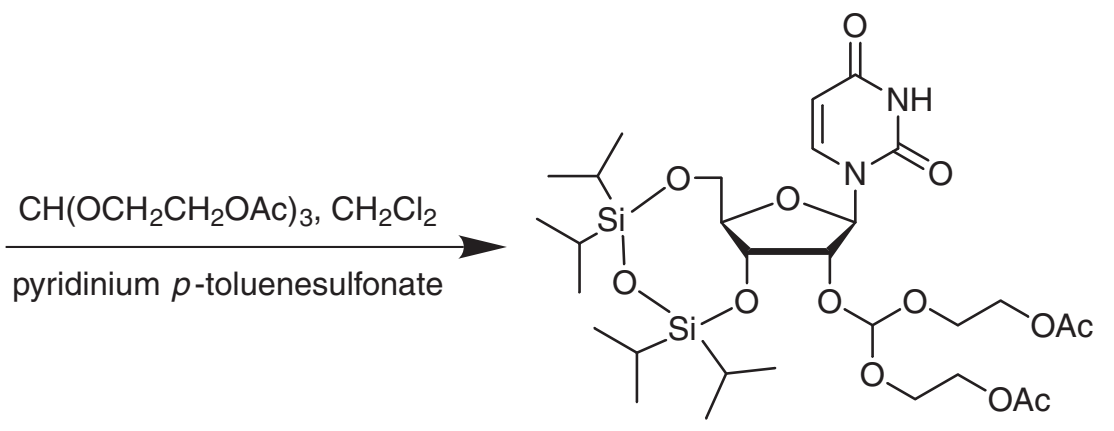

3

Figure 2.10.3 2'-ACE protection. Synthesis of $3^{\prime}, 5^{\prime}-O$-(tetraisopropyldisiloxane-1,3-diyl)-2'-O-bis(acetoxyethyloxy)methyl uridine from $3^{\prime}, 5^{\prime}-O$-(tetraisopropyldisiloxane-1,3-diyl)uridine.

\section{Perform 2'-O-ACE protection (S.3)}

13. Dry the product $\mathbf{S . 2}$ by co-evaporating twice with $100-\mathrm{mL}$ portions of $\mathrm{MeCN}$.

14. Add, in order, tris(2-acetoxyethyl) orthoformate (2.3 equiv per equiv S.2), dichloromethane $(2 \mathrm{~mL}$ per $\mathrm{mmol} \mathbf{S . 2})$, and pyridinium $p$-toluenesulfonate $(0.2$ equiv per equiv S.2). Stir reaction at room temperature.

15. To check the progress of the reaction by TLC, dilute a $40-\mu \mathrm{L}$ aliquot of the reaction solution with $40 \mu \mathrm{L}$ TEA and $200 \mu \mathrm{L} \mathrm{CH}_{2} \mathrm{Cl}_{2}$. Analyze 1 to $5 \mu \mathrm{L}$ of this solution using a solvent system of $5 \%(\mathrm{v} / \mathrm{v}) \mathrm{MeOH}$ in $\mathrm{CH}_{2} \mathrm{Cl}_{2}$.

The product, 3',5'-O-TIPS-2'-O-ACE-uridine (S.3; Fig. 2.10.3), typically migrates with a slightly faster $R_{f}$ than the starting material.

16. After TLC analysis shows that the reaction is progressing well ( $\sim 60 \mathrm{~min})$, add 4-tert-butyldimethylsiloxy-3-penten-2-one (1.8 equiv per equiv S.2) and stir the reaction for an additional 36 to $48 \mathrm{hr}$ at room temperature.

If necessary, the reaction can be accelerated by gently refluxing at $38^{\circ}$ to $40^{\circ} \mathrm{C}$. The solution should appear clear, with a slightly yellow or orange color. If the reaction still appears to be sluggish or stagnant, an additional aliquot of pyridinium p-toluenesulfonate (up to 1.0 equiv total) can be added.

The 4-tert-butyldimethylsiloxy-3-penten-2-one is added to drive the reaction to completion. The 2'-ACE reaction is an equilibrium exchange of the 2'-hydroxyl with one of the three alcohols in the orthoester reagent. 4-tert-Butyldimethylsiloxy-3-penten-2-one reacts selectively with the primary hydroxyl of the liberated 2-acetoxy-ethanol byproduct, rendering it unable to react further, and thereby forcing the equilibrium to the 2 '-ACE product.

17. When TLC indicates that the reaction is $\geq 95 \%$ complete, add TEMED ( 0.5 equiv per equiv S.2) to neutralize the reaction mixture.

4-tert-Butyldimethylsiloxy-3-penten-2-one is UV absorbing and volatile. It appears on the TLC plate as a dark spot or as a pair of spots (two isomers) migrating at the solvent front. Upon standing, the spots will slowly disappear.

If additional pyridinium p-toluenesulfonate was added to accelerate the reaction, additional TEMED (up to 2.5 equiv) must be added to compensate.

Protection of

Nucleosides for Oligonucleotide Synthesis

2.10 .5

Supplement 16 
18. Prepare a flash chromatography column with $250 \mathrm{~g}$ silica gel 60 using a solvent mix of 75:25 (v/v) hexane/EtOAc containing 0.5\% (v/v) TEMED. Dilute the reaction solution with $2 \mathrm{vol}(90 \mathrm{~mL})$ hexane and load this mixture directly onto the column.

Only TEMED should be used as the base. TEA or another tertiary amine should not be used. TEMED-HF is used to deprotect the 5'-and 3'-hydroxyls in the next step. If TEA is present in that step, the HF salt of TEA will be generated. The TEA-HF salt migrates on silica gel and is difficult or impossible to separate from the 2'-O-ACE nucleoside product. This problem does not occur with the more polar TEMED-HF salt.

19. Elute the product using 49:50:0.5:0.5 (v/v/v/v) hexane/EtOAc/MeOH/TEMED (typically $2 \mathrm{~L}$ ). Collect 20-mL fractions and monitor by TLC.

It is very important to remove the several small impurities that elute just ahead of the desired product. If present, they severely complicate subsequent purifications. Therefore, when the product begins to elute, collect smaller fractions and analyze carefully by TLC.

Because the excess orthoester reagent and any remaining starting material often co-elute with the product, the product cannot be fully characterized at this point. Carry it through to the next reaction, in which the TIPS protecting group will be removed. After the next reaction, all impurities can be easily removed by column chromatography, and the pure product can be readily characterized.

Remove $3^{\prime}, 5^{\prime}$-TIPS protection (S.4)

20. To the semi-pure $\mathbf{S . 3}$, add $2 \mathrm{~mL} \mathrm{MeCN}$ per mmol of starting protected uridine in step 13).

21. Prepare TEMED-HF reagent in a separate flask as follows. Place $2 \mathrm{~mL} \mathrm{MeCN}$ per mmol S.2 in a separate vessel on ice. Add 5 equiv TEMED (per equiv S.2). Then slowly add (over $5 \mathrm{~min}$ ) $48 \%$ (w/v) aqueous HF (3.5 equiv per equiv S.2). Stir on ice for $5 \mathrm{~min}$.

22. Slowly add TEMED-HF solution to the nucleoside solution over $2 \mathrm{~min}$, with stirring. Stir reaction at room temperature for $\sim 4 \mathrm{hr}$. Monitor the progress of the reaction by TLC on silica gel using $8 \%(\mathrm{v} / \mathrm{v}) \mathrm{MeOH}$ in $\mathrm{CH}_{2} \mathrm{Cl}_{2}$ until it is complete.

The desired product moves considerably more slowly on the TLC plate than does the starting material in this solvent systems.

23. Remove $\mathrm{MeCN}$ from the reaction on the rotary evaporator. When most of the solvent is removed, add $100 \mathrm{~mL}$ dichloromethane, $20 \mathrm{~mL}$ hexane, and $2 \mathrm{~mL}$ TEMED. Mix well.

24. Slowly load this solution directly onto a $50 \times 600-\mathrm{mm}$ flash chromatography column containing $250 \mathrm{~g}$ silica gel poured in 15:85 (v/v) hexane/EtOAc containing 0.5\% (v/v) TEMED.

The solution should be loaded slowly onto the column using gravity flow, as heat tends to be generated and may disrupt the silica gel bed.

25. Elute the product using 94:6 (v/v) EtOAc/MeOH containing 0.5\% (v/v) TEMED (typically $2 \mathrm{~L}$ ). Collect $20-\mathrm{mL}$ fractions.

The molecular weight of 2'-O-ACE-uridine (S.4; Fig. 2.10.4) is $462 \mathrm{~g} / \mathrm{mol}$. The yield is $11.83 \mathrm{~g}(65 \%$ to $80 \%)$ overall ( steps 13 to 25 combined). ${ }^{1} H N M R\left(C D C l_{3}\right): \delta 7.79(d, J=$ $8.4 \mathrm{~Hz}, 1 \mathrm{H}), 5.80(\mathrm{~d}, \mathrm{~J}=4.0 \mathrm{~Hz}, 1 \mathrm{H}), 5.66(\mathrm{~d}, \mathrm{~J}=8.0 \mathrm{~Hz}, 1 \mathrm{H}), 5.42(\mathrm{~s}, 1 \mathrm{H}), 4.45-4.43(\mathrm{~m}$, $1 H), 4.26-4.23(\mathrm{~m}, 1 \mathrm{H}), 4.15-4.10(\mathrm{~m}, 4 H), 4.02-4.00(\mathrm{~m}, 1 \mathrm{H}), 3.87-3.82(\mathrm{~m}, 1 \mathrm{H})$, 3.74-3.66 (m, 5H), $1.98(\mathrm{~s}, 3 \mathrm{H}), 1.97(\mathrm{~s}, 3 \mathrm{H}) .{ }^{13} \mathrm{CNMR}\left(\mathrm{CDCl}_{3}\right): \delta 171.25,171.22,164.2$, 150.7, 141.8, 112.4, 102.2, 89.2, 84.9, 76.2, 69.4, 63.1, 63.0, 62.97, 62.8, 61.2, 30.9, 20.84, 20.82. Exact mass calculated for $\mathrm{C}_{18} \mathrm{H}_{26} \mathrm{~N}_{2} \mathrm{O}_{12}: 462.2$; found by $\operatorname{ESMS}(\mathrm{M}+\mathrm{H}): 463$. 


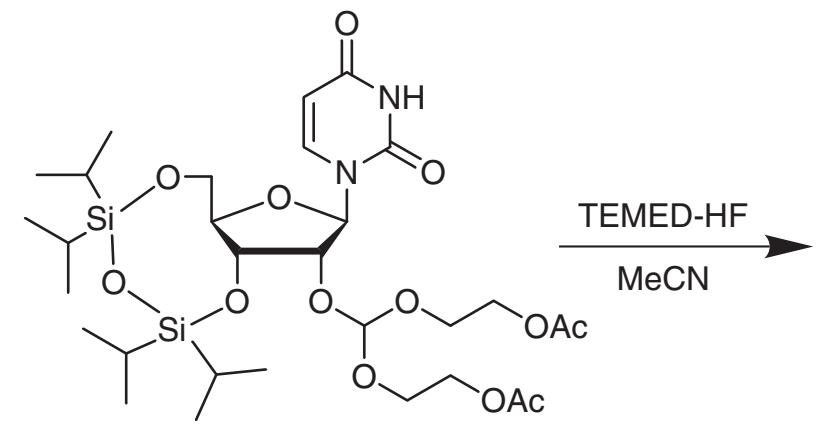

3

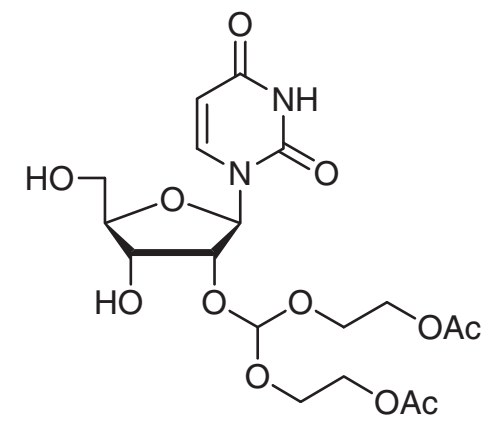

4

Figure 2.10.4 Removal of $3^{\prime}, 5^{\prime}$-protection. Synthesis of 2'-O-bis(acetoxyethyloxy)methyl uridine from $3^{\prime}, 5^{\prime}$-O-(tetraisopropyldisiloxane-1,3-diyl)-2'-O-bis(acetoxyethyloxy)methyl uridine. TEMED, $N, N, N^{\prime}, N^{\prime}$-tetramethylethylenediamine.

Perform 5'-O-silylation (S.5)

26. Dissolve $\mathbf{S . 4}$ in $5 \mathrm{~mL} \mathrm{CH}_{2} \mathrm{Cl}_{2}$ (per mmol S.4) and add diisopropylamine (1 equiv per equiv S.4). Cool solution to $0^{\circ} \mathrm{C}$ with an ice bath.

27. In a separate flask, dissolve 1.5 equiv $\mathrm{BzH}-\mathrm{Cl}$ (per equiv $\mathbf{S . 4}$ ) in $\mathrm{CH}_{2} \mathrm{Cl}_{2}(2 \mathrm{~mL} / \mathrm{g}$ $\mathrm{BzH}-\mathrm{Cl})$.

28. Add 1 equiv diisopropylamine (per equiv $\mathrm{BzH}-\mathrm{Cl}$ ) to the silyl chloride solution (step 27) slowly over $1 \mathrm{~min}$. Shake resulting solution for $5 \mathrm{~min}$ and ensure that it remains clear.

If the solution does not clear after several minutes, the mixture is not sufficiently anhydrous, and the solution should be made again using fresh, dry dichloromethane and N,N-diisopropylamine. These materials can be conveniently dried by storing them over 4 A molecular sieves for at least $24 \mathrm{hr}$.

29. Slowly add the diisopropylamine-activated silylating reagent (step 28) to the nucleoside solution (step 26) while stirring at $0^{\circ} \mathrm{C}$. Begin by adding 0.5 equiv aliquots of the silylating reagent, and then taper to smaller aliquots as the reaction proceeds to completion. Add each aliquot over a period of 10 to $15 \mathrm{~min}$. Monitor the reaction by TLC on silica gel after each addition using $5 \%(\mathrm{v} / \mathrm{v}) \mathrm{MeOH} / \mathrm{CH}_{2} \mathrm{Cl}_{2}$. Continue to add the silylating solution until the start material disappears, and then add slightly more to ensure that any $3^{\prime}$-O-silylated nucleoside is converted to the $3^{\prime}, 5^{\prime}$-O-disilylated nucleoside. Keep the total reaction time $<3 \mathrm{hr}$.

The reaction will start out clear, but will turn cloudy as the silylating solution is added.

The silylating reagent appears to react slightly with the nucleobases on uridine and guanosine, requiring $>1.0$ equiv to $5^{\prime}$-protect all of the starting material.

The silylating reagent reacts preferentially with the primary $5^{\prime}$-hydroxyl but will also react with the 3'-hydroxyl. The 3'-O-silylated nucleoside contaminant chromatographs immediately ahead of the desired 5'-O-silylated product, and is difficult to separate. However, the $3^{\prime}, 5^{\prime}$-bis-silylated product runs very quickly in the TLC solvent given, near the solvent front. It is well separated from the desired $5^{\prime}-O$-silylated product and can be removed easily during the chromatography step. Therefore, the reaction is continued until all of the starting material is consumed, in order to also 5'-O-silylate any 3'-O-silylated nucleoside that has formed.

It is best to do this reaction steadily, without pausing for an extended time between additions of silyl reagent. As soon as TLC shows the reaction is complete, immediately work up the reaction.

Protection of Nucleosides for Oligonucleotide Synthesis

\subsection{0 .7}

Supplement 16 


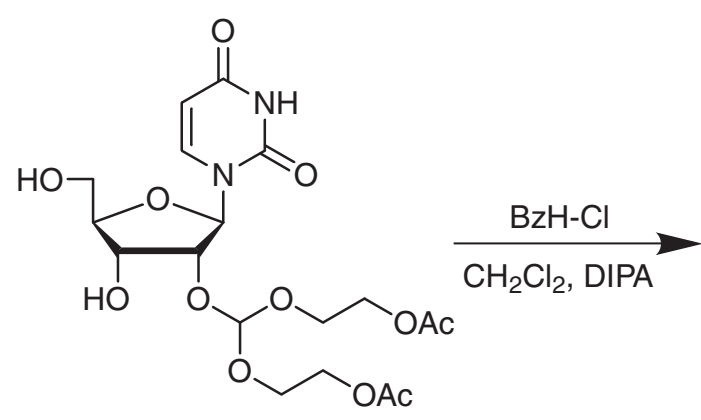

4

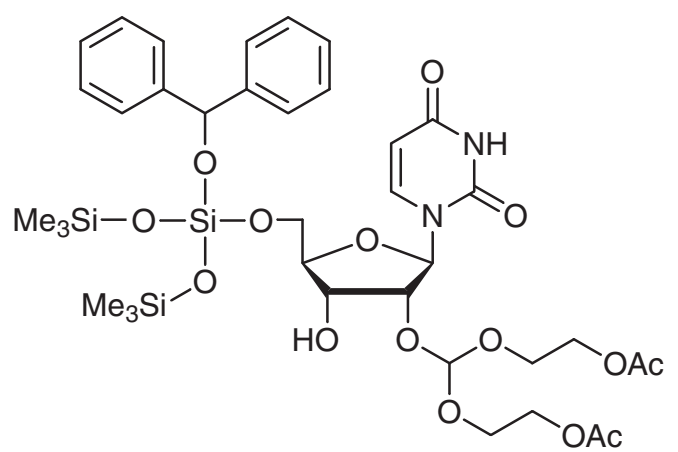

5

Figure 2.10.5 5'-Silylation. Synthesis of 5'-O-benzhydroxy-bis(trimethylsilyloxy)silyl-2'-O-bis(acetoxyethyloxy)methyl uridine from 2'-O-bis(acetoxyethyloxy)methyl uridine. $\mathrm{BzH}-\mathrm{Cl}$, benzhydroxy-bis(trimethylsilyloxy)silyl chlorosilane; DIPA, $\mathrm{N}, \mathrm{N}$-diisopropylamine.

30. Immediately after the reaction is complete according to TLC, extract the reaction mixture with $200 \mathrm{~mL}$ of $8 \%$ (w/v) aqueous $\mathrm{NaHCO}_{3}$, followed by $200 \mathrm{~mL}$ saturated aqueous $\mathrm{NaCl}$. Dry the organic phase over $50 \mathrm{~g} \mathrm{Na}_{2} \mathrm{SO}_{4}$ and concentrate on the rotary evaporator.

31. Dissolve the residue in a solution of $50 \mathrm{~mL} \mathrm{CH}_{2} \mathrm{Cl}_{2} / 150 \mathrm{~mL}$ hexane/1 mL TEA. Load onto a $50 \times 600-\mathrm{mm}$ flash chromatography column filled with $250 \mathrm{~g}$ silica gel 60 in 80:20 (v/v) hexane/acetone containing 0.5\% (v/v) TEA.

32. Elute the product using 50:30:20 (v/v/v) hexane/EtOAc/acetone containing $0.5 \%$ (v/v) TEA (typically $2 \mathrm{~L}$ ). Collect $20-\mathrm{mL}$ fractions.

The molecular weight of 5'-O-BzH-2'-O-ACE-uridine (S.5; Fig. 2.10.5) is $850 \mathrm{~g} / \mathrm{mol}$. The yield is $17.43 \mathrm{~g}(75 \%$ to $90 \%) .{ }^{1} \mathrm{H} \mathrm{NMR}\left(\mathrm{CDCl}_{3}\right): \delta 7.79(\mathrm{~d}, \mathrm{~J}=8.0 \mathrm{~Hz}, 1 \mathrm{H}), 7.32-7.18$ $(m, 10 H), 5.99(d, J=3.2 H z, 1 H), 5.92-5.89(m, 1 H), 5.48-5.47(m, 1 H), 5.46(s, 1 H)$, 4.25-4.13 (m, 6H), 4.02-3.84 ( $m, 2 H), 3.83-3.74(m, 5 H), 2.03(s, 3 H), 2.01(s, 3 H), 1.89$

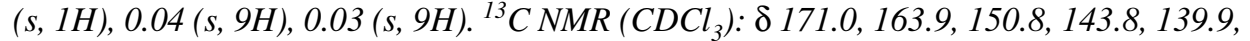
$128.4,127.5,126.4,126.3,112.7,102.4,87.6,84.2,77.1,68.8,63.2,63.1,63.06,63.02$, 61.6, 20.94, 20.90, 1.6. Exact mass calculated for $\mathrm{C}_{37} \mathrm{H}_{54} \mathrm{~N}_{2} \mathrm{O}_{15} \mathrm{Si}_{3}: 850.3$; found by ESMS $(M+H): 851$.

\section{Prepare 3'-phosphoramidite (S.6)}

33. Co-evaporate $\mathbf{S . 5}$ once with $2.5 \mathrm{~mL} \mathrm{MeCN}$ per mmol S.5. Add $2 \mathrm{~mL} \mathrm{CH}_{2} \mathrm{Cl}_{2}$ per mmol S.5, cap the reaction flask with a rubber septum, and stir the solution at $0^{\circ} \mathrm{C}$ in an ice bath.

34. In a separate flask under anhydrous conditions, dilute the phosphinylating reagent bis( $N, N$-diisopropylamino)methoxyphosphine (1.25 equiv per equiv $\mathbf{S . 5}$ ) with $\mathrm{CH}_{2} \mathrm{Cl}_{2}(2 \mathrm{~mL}$ per mmol phosphine). Add a solution of $0.45 \mathrm{M} 1 \mathrm{H}$-tetrazole in $\mathrm{MeCN}$ ( 0.5 equiv tetrazole per equiv $\mathbf{S . 5}$ ) and shake for $5 \mathrm{~min}$.

35. Add the solution of activated phosphinylating reagent to the well-stirred solution of nucleoside at room temperature.

36. After $15 \mathrm{~min}$, remove a $40-\mu \mathrm{L}$ aliquot of the crude reaction mixture and add to 200 $\mu \mathrm{L}$ of $\mathrm{CH}_{2} \mathrm{Cl}_{2}$ containing 10\% (v/v) TEA. Spot on a TLC plate pre-run in 60:30:10 $(\mathrm{v} / \mathrm{v} / \mathrm{v})$ hexane/ $\mathrm{CH}_{2} \mathrm{Cl}_{2} / \mathrm{TEA}$. Develop the plate in this solvent mixture to check that the reaction is progressing. Continue to stir at room temperature until the reaction is complete by TLC analysis ( 12 to $18 \mathrm{hr}$ ).

The desired product will move more quickly on the plate than the starting material. 


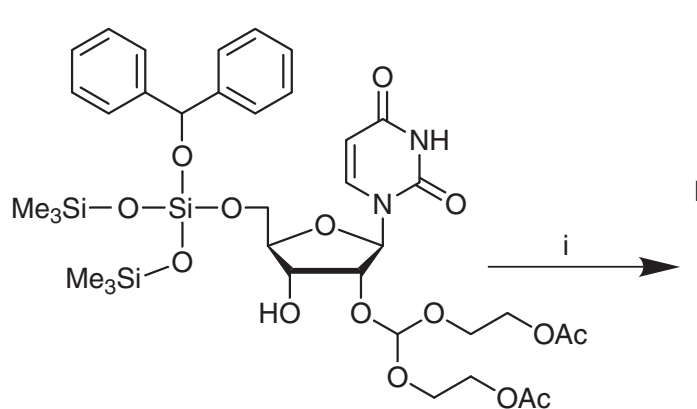

5

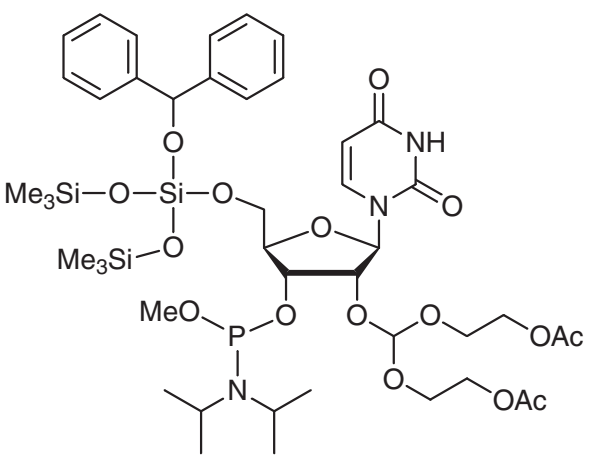

6

Figure 2.10.6 Preparation of the phosphoramidite monomer for oligoribonucleotide synthesis. Synthesis of 5'-O-benzhydroxy-bis(trimethylsilyloxy)silyl-2'-O-bis(acetoxyethyloxy)methyl-3'-O-(N,N-diisopropylamino)methoxyphosphinyl uridine from 5'-O-benzhydroxy-bis(trimethylsilyloxy)silyl-2'-O-bis(acetoxyethyloxy)methyl uridine. i: bis( $N, N$-diisopropylamino)methoxyphosphine; $1 \mathrm{H}$-tetrazole, $\mathrm{CH}_{2} \mathrm{Cl}_{2}, 12 \mathrm{hr}$.

37. Add 10 equiv EtOH per equiv $\mathbf{S . 5}$ to quench the excess phosphine. Continue stirring for $30 \mathrm{~min}$. Dry reaction on the rotary evaporator.

38. Purify the product on silica gel. Take up the residue from a $20-\mathrm{mmol}$ reaction in a solution of $25 \mathrm{~mL} \mathrm{CH}_{2} \mathrm{Cl}_{2} / 125 \mathrm{~mL}$ hexane/ $1 \mathrm{~mL}$ TEA and load onto a $50 \times 600-\mathrm{mm}$ flash chromatography column filled with $25 \mathrm{~mL}$ silica/g product in a solvent mix of 94:5:1 (v/v/v) hexane/ $\mathrm{CH}_{2} \mathrm{Cl}_{2} / \mathrm{TEA}$.

39. Elute the product with 75:25 (v/v) hexane/acetone containing $0.5 \%(\mathrm{v} / \mathrm{v})$ TEA (typically $2 \mathrm{~L}$ ). Collect $20-\mathrm{mL}$ fractions, monitor by TLC (step 36), and pool fractions containing purified product.

40. Co-evaporate the pooled fractions with $100 \mathrm{~mL}$ toluene to ensure the amidite is not concentrated down into TEA. Finish with two co-evaporations using $100 \mathrm{~mL}$ portions of $\mathrm{MeCN}$ under high vacuum.

The product, 5'-O-benzhydroxy-bis(trimethylsilyloxy)silyl-2'-O-bis(acetoxyethyloxy)methyl-3'-O-(N,N-diisopropylamino)methoxyphosphinyl uridine (S.6; Fig. 2.10.6), is a clear syrup, often pale yellow in color. The molecular weight is $1011 \mathrm{~g} / \mathrm{mol}$; the yield is $18.65 \mathrm{~g}(75 \%$ to $95 \%) .{ }^{1} \mathrm{H} \mathrm{NMR}\left(\mathrm{CDCl}_{3}\right.$, mixture of diasteromers): $\delta 8.08(\mathrm{~b}, 1 \mathrm{H}), 7.81$ and 7.80 (each as $d, J=8.0 \mathrm{~Hz}, 1 \mathrm{H}$ ), 7.34-7.21 (m, 10H), 6.05 and 6.01 (each as $d, J=$ $4.4 \mathrm{~Hz}, 1 \mathrm{H}$ ), 5.93 and 5.92 (each as $\mathrm{s}, 1 \mathrm{H}$ ), 5.58 and 5.45 (each as $\mathrm{s}, 1 \mathrm{H}$ ), 5.41 and 5.35 (each as $d, J=8.0 \mathrm{~Hz}, 1 \mathrm{H}$ ), 4.34-4.13 ( $\mathrm{m}, 8 \mathrm{H}$ ), 3.99-3.96 and 3.92-3.89 (each as $\mathrm{m}, 1 \mathrm{H}$ ), 3.82-3.73 ( $m, 5 H$ ), 3.60-3.57 ( $m, 2 H$ ), 3.38 and 3.31 (each as $d, J=12.0 \mathrm{~Hz}, 3 \mathrm{H}$ ), 2.08 and 2.06 (each as $s, 6 H), 1.20-1.15(\mathrm{~m}, 12 \mathrm{H}$ ), and 0.06, 0.06, 0.04, and 0.02 (each as $s$, $18 \mathrm{H}) .{ }^{31} \mathrm{P} \mathrm{NMR}\left(\mathrm{CDCl}_{3}\right.$, mixture of diasteromers): $\delta$ 152.2, 152.0. Exact mass calculated for $\mathrm{C}_{44} \mathrm{H}_{70} \mathrm{~N}_{3} \mathrm{O}_{16} \mathrm{PSi}_{3}$ : 1011.4; found by ESMS $(M+H): 1012$.

Protection of

Nucleosides for Oligonucleotide Synthesis

2.10.9

Supplement 16 


\section{SYNTHESIS OF 2'-ACE-PROTECTED ADENOSINE RIBONUCLEOSIDE PHOSPHORAMIDITE}

The procedure for the synthesis of the $N^{6}$-benzoyl-5'-O-silyl-2'-O-ACE-adenosine $3^{\prime}-O$ phosphoramidite is generally the same as for the uridine derivative (see Basic Protocol). The only significant changes occur in the solvent mixtures used for flash chromatographic purification of the various intermediates. Isolated yields per step are generally within $\pm 10 \%$ of the yields obtained for the uridine derivatives. The TLC conditions for the analysis of the crude reaction mixtures described in the Basic Protocol may be used for analysis in this protocol as well. Although the $R_{\mathrm{f}}$ values of the adenosine derivatives will differ slightly from those of the uridine derivatives, the differences between starting material and desired product will be similar at each step.

\section{Additional Materials (also see Basic Protocol)}

$N^{6}$-Benzoyladenosine (337 g/mol; Monomer Sciences)

1. Synthesize $N^{6}$-benzoyl-3', $5^{\prime}$-O $O$-TIPS-adenosine from $N^{6}$-benzoyladenosine as described (see Basic Protocol, steps 1 to 12). For flash chromatography (steps 10 and 11), use a solvent system of 40:60 (v/v) hexane/EtOAc.

The product has an $R_{f}$ of 0.5 under these conditions. Its molecular weight is $579 \mathrm{~g} / \mathrm{mol} .{ }^{1} \mathrm{H}$ $\mathrm{NMR}\left(\mathrm{CDCl}_{3}\right): \delta 9.78(\mathrm{~b}, 1 \mathrm{H}), 8.58(\mathrm{~s}, 1 \mathrm{H}), 8.27(\mathrm{~s}, 1 \mathrm{H}), 6.02(\mathrm{~s}, 1 \mathrm{H}), 4.94-4.91(\mathrm{~m}, 1 \mathrm{H})$, $4.56(d, J=5.2 \mathrm{~Hz}, 1 \mathrm{H}), 4.39(\mathrm{~b}, 1 \mathrm{H}), 4.09-4.06(\mathrm{~m}, 2 \mathrm{H}), 3.96-3.92(\mathrm{~m}, 1 \mathrm{H}), 3.28-3.24$ (m, 1H), 1.20-1.17 (m, 6H), 1.03-0.84 (m, 28H). ${ }^{13} \mathrm{CNMR}\left(\mathrm{CDCl}_{3}\right): \delta 176.9,152.3,150.4$, 142.0, 122.7, 81.9, 80.8, 74.9, 70.2, 61.1, 35.6, 19.1, 19.07, 17.3, 17.15, 17.14, 17.13, 16.9, 16.8, 16.79, 16.7, 13.1, 12.8, 12.6, 12.4. Exact mass calculated for $\mathrm{C}_{26} \mathrm{H}_{45} \mathrm{~N}_{5} \mathrm{O}_{6} \mathrm{Si}_{2}: 579.3$; found by $\operatorname{ESMS}(M+H): 580$.

2. Synthesize $N^{6}$-benzoyl-3', $5^{\prime}-O$-TIPS-2'-O-ACE-adenosine as described (see Basic Protocol, steps 13 to 19$)$. Elute the product (step 19) using 55:42:3:0.5 (v/v/v/v) hexane/EtOAc/MeOH/TEMED.

Characterization data are not provided, because the crude product is directly carried to the next synthesis step.

3. Synthesize $N^{6}$-benzoyl-2'-O-ACE-adenosine as described (see Basic Protocol, steps 20 to 25). Elute the product (step 25) using 95:5 (v/v) EtOAc/MeOH containing 0.5\% (v/v) TEMED.

The molecular weight of the product is $555 \mathrm{~g} / \mathrm{mol} .{ }^{1} \mathrm{H} \mathrm{NMR}\left(\mathrm{CDCl}_{3}\right): \delta 9.23(\mathrm{~b}, \mathrm{lH}), 8.63$ $(s, 1 H), 8.14(s, 1 H), 5.99(d, J=7.6 H z, 1 H), 5.97(b, 1 H), 5.18(s, 1 H), 5.02(d d, J=4.8$ $\mathrm{Hz}, 7.2 \mathrm{~Hz}, 1 \mathrm{H}), 4.48(\mathrm{~d}, \mathrm{~J}=4.8 \mathrm{~Hz}, 1 \mathrm{H}), 4.31-4.28(\mathrm{~m}, 1 \mathrm{H}), 4.00-3.90(\mathrm{~m}, 5 \mathrm{H}), 3.72-3.68$ $(\mathrm{m}, 1 \mathrm{H}), 3.60-3.55(\mathrm{~m}, 3 \mathrm{H}), 3.43-3.38(\mathrm{~m}, 2 \mathrm{H}), 3.24-3.20(\mathrm{~m}, 1 \mathrm{H}), 1.98(\mathrm{~s}, 3 \mathrm{H}), 1.97(\mathrm{~s}$, $3 \mathrm{H}), 1.23(\mathrm{~d}, \mathrm{~J}=7.2 \mathrm{~Hz}, 6 \mathrm{H}) .{ }^{13} \mathrm{CNMR}\left(\mathrm{CDCl}_{3}\right): \delta 176.7,170.9,152.1,150.2,143.3$, 123.5, 112.5, 89.2, 87.7, 76.3, 71.9, 63.3, 63.1, 62.7, 62.6, 62.57, 36.1, 20.8, 19.2. Exact mass calculated for $\mathrm{C}_{23} \mathrm{H}_{33} \mathrm{~N}_{5} \mathrm{O}_{11}: 555.2$; found by $\operatorname{ESMS}(\mathrm{M}+\mathrm{H}): 556$.

4. Synthesize $N^{6}$-benzoyl-5'-O-BzH-2'-O-ACE-adenosine as described (see Basic Protocol, steps 26 to 32). Elute the product (step 32) using 45:35:20 (v/v/v) hexane/EtOAc/acetone containing $0.5 \%$ (v/v) TEA.

The molecular weight of the product is $943 \mathrm{~g} / \mathrm{mol} .{ }^{1} \mathrm{H} \mathrm{NMR}\left(\mathrm{CDCl}_{3}\right): \delta 8.68(\mathrm{~b}, 1 \mathrm{H}), 8.67$ $(s, 1 H), 8.29(s, 1 H), 7.33-7.15(m, 10 H), 6.21(d, J=5.2 \mathrm{~Hz}, 1 H), 5.91(s, 1 H), 5.31(s$, $1 H), 4.83-4.79(m, 1 H), 4.36-4.33(m, 1 H), 4.13-4.09(m, 3 H), 4.05-4.03(m, 2 H)$, 3.91-3.87 (m, lH), 3.78-3.75 (m, lH), 3.69-3.62 (m, 3H), 3.52-3.46 (m, $1 H), 3.28-3.24$ $(m, 1 H), 3.05(m, 1 H), 1.99(s, 6 H), 1.27(d, J=6.8 \mathrm{~Hz}, 6 H), 0.04(s, 9 H), 0.03(s, 9 H)$. ${ }^{13} \mathrm{CNMR}\left(\mathrm{CDCl}_{3}\right): \delta 176.4,170.8,152.6,151.2,149.4,144.0,141.7,128.3,127.3,126.4$, 122.3, 112.5, 88.6, 84.9, 77.0, 76.97, 70.5, 63.1, 63.0, 62.8, 62.7, 62.6, 36.1, 20.8, 19.3, 1.5. Exact mass calculated for $\mathrm{C}_{42} \mathrm{H}_{61} \mathrm{~N}_{5} \mathrm{O}_{14} \mathrm{Si}_{3}$ : 943.4; found by $\operatorname{ESMS}(M+H)$ : 944 . 


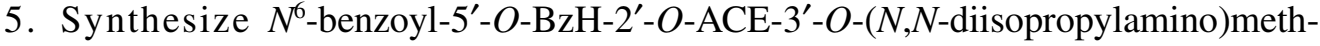
oxyphosphinyl adenosine as described (see Basic Protocol, steps 33 to 40). Elute the product (step 39) with 70:30 (v/v) hexane/acetone containing 0.5\% (v/v) TEA.

The product (Fig. 2.10.1) is a clear syrup, often pale yellow in color. The molecular weight is $1105 \mathrm{~g} / \mathrm{mol}^{.}{ }^{\mathrm{l}} \mathrm{H} \mathrm{NMR}\left(\mathrm{CDCl}_{3}\right.$, mixture of diasteromers $): \delta 8.68$ and 8.67 (each as $\left.\mathrm{s}, 1 \mathrm{H}\right)$; $8.40(b, 1 H) ; 8.29$ and 8.25 (each as $s, 1 H)$; 7.35-7.17 ( $m, 10 H) ; 6.25$ and 6.23 (each as $d, J=4.4 \mathrm{~Hz}, 1 \mathrm{H}) ; 5.93$ and 5.91 (each as $s, 1 H) ; 5.41$ and 5.31 (each as $s, 1 H) ; 4.85-4.82$ $(\mathrm{m}, 1 \mathrm{H}) ; 4.59-4.55(\mathrm{~m}, 1 \mathrm{H}) ; 4.29-4.21(\mathrm{~m}, 1 \mathrm{H}) ; 4.10-3.91(\mathrm{~m}, 5 \mathrm{H}) ; 3.78-3.54(\mathrm{~m}, \mathrm{7H})$; 3.40 and 3.33 (each as $d, J=12.0 \mathrm{~Hz}, 3 \mathrm{H}$ ); 3.32-3.26 (m, $1 \mathrm{H}) ; 2.02$ and 2.00 (each as $s$, $6 H) ; 1.31(d, J=6.8 \mathrm{~Hz}, 6 H) ; 1.28-1.14(\mathrm{~m}, 12 \mathrm{H}) ; 0.06,0.04,0.03$, and 0.02 (each as $\mathrm{s}$, 18H). ${ }^{31} \mathrm{P} \mathrm{NMR}\left(\mathrm{CDCl}_{3}\right.$, mixture of diasteromers $): \delta$ 152.2, 151.4. Exact mass calculated for $\mathrm{C}_{49} \mathrm{H}_{77} \mathrm{~N}_{6} \mathrm{O}_{15} \mathrm{PSi}_{3}$ : 1104.5; found by $\operatorname{ESMS}(\mathrm{M}+\mathrm{H}): 1106$.

\section{SYNTHESIS OF 2'-ACE-PROTECTED GUANOSINE RIBONUCLEOSIDE PHOSPHORAMIDITE}

The procedure for the synthesis of the $N^{2}$-isobutyryl-5'-O-silyl-2'-O-ACE-guanosine $3^{\prime}-O$-phosphoramidite is generally the same as for the uridine derivative (see Basic Protocol). The only significant changes occur in the solvent mixtures used for flash chromatographic purification of the various intermediates. Isolated yields per step are generally within $\pm 10 \%$ of the yields obtained for the uridine derivatives. The TLC conditions for the analysis of the crude reaction mixtures described in the Basic Protocol may be used for analysis in this protocol as well. Although the $R_{\mathrm{f}}$ values of the guanosine derivatives will differ slightly from those of the uridine derivatives, the differences between starting material and desired product will be similar at each step.

Additional Materials (also see Basic Protocol)

$N^{2}$-Isobutyrylguanosine (353 g/mol; Monomer Sciences)

1. Synthesize $N^{2}$-isobutyryl-3', $5^{\prime}$-O-TIPS-guanosine from $N^{2}$-isobutyrylguanosine as described (see Basic Protocol, steps 1 to 12). For flash chromatography (steps 10 and 11), use a solvent system of 30:70 (v/v) hexane/EtOAc.

The product has an $R_{f}$ of 0.5 under these conditions. Its molecular weight is $595 \mathrm{~g} / \mathrm{mol} .{ }^{1} \mathrm{H}$ $\operatorname{NMR}\left(\mathrm{CDCl}_{3}\right): \delta 12.30(\mathrm{~b}, 1 \mathrm{H}), 10.66(\mathrm{~b}, 1 \mathrm{H}), 7.94(\mathrm{~s}, 1 \mathrm{H}), 5.72(\mathrm{~m}, 1 \mathrm{H}), 4.45-4.42(\mathrm{~m}$, $1 H), 4.28-4.26(m, 1 H), 4.14-4.09(m, 2 H), 4.01-3.93(m, 1 H), 2.94-2.88(m, 1 H)$, $1.26-1.21(\mathrm{~m}, 6 H), 1.08-0.86(\mathrm{~m}, 28 H) .{ }^{13} \mathrm{CNMR}\left(\mathrm{CDCl}_{3}\right): \delta 180.1,156.1,148.4,148.1$, 136.8, 121.3, 89.1, 81.7, 75.3, 69.6, 60.6, 36.2, 31.7, 36.2, 19.2, 19.1, 17.6, 17.43, 17.41, 17.3, 17.1, 16.9, 13.5, 13.1, 13.0, 12.6. Exact mass calculated for $\mathrm{C}_{26} \mathrm{H}_{45} \mathrm{~N}_{5} \mathrm{O}_{7} \mathrm{Si}_{2}: 595.3$; found by ESMS $(M+H): 596$.

2. Synthesize $N^{2}$-isobutyryl-3', $5^{\prime}$-O $O$-TIPS-2'-O-ACE-guanosine as described (see Basic Protocol, steps 13 to 19). Elute the product (step 19) using 47:50:3:0.5 (v/v/v/v) hexane/EtOAc/MeOH/TEMED.

Characterization data are not provided, because the crude product is directly carried to the next synthesis step.

3. Synthesize $N^{2}$-isobutyryl-2'-O-ACE-guanosine as described (see Basic Protocol, steps 20 to 25). Elute the product (step 25) using 64:30:6 (v/v/v) EtOAc/acetone $/ \mathrm{MeOH}$ containing $0.5 \%(\mathrm{v} / \mathrm{v})$ TEMED.

The molecular weight of the product is $571 \mathrm{~g} / \mathrm{mol} .{ }^{1} \mathrm{H} \mathrm{NMR}\left(\mathrm{CDCl}_{3}\right): \delta 12.30(\mathrm{~b}, 1 \mathrm{H}), 10.38$ $(b, 1 H), 8.15(s, 1 H), 5.93(d, J=4.4 H z, 1 H), 5.37(s, 1 H), 4.92(b, 1 H), 4.73-4.70(m$, $1 H), 4.57-4.45(m, 1 H), 4.37(b, 1 H), 4.12-4.02(m, 5 H), 3.89-3.85(m, 1 H), 3.77-3.74$ $(\mathrm{m}, 1 \mathrm{H}), 3.67-3.56(\mathrm{~m}, 4 H), 2.82-2.74(\mathrm{~m}, 1 \mathrm{H}), 1.97(\mathrm{~s}, 3 H), 1.95(\mathrm{~s}, 3 H), 1.17-1.14(\mathrm{~m}$, $6 H) .{ }^{13} \mathrm{C} \mathrm{NMR}\left(\mathrm{CDCl}_{3}\right): \delta 180.3,171.3,171.2,155.7,148.3,139.1,120.9,112.4,87.5$, 85.6, 76.7, 70.0, 63.2, 63.1, 62.9, 62.3, 61.5, 35.9, 31.0, 20.9, 19.0. Exact mass calculated for $\mathrm{C}_{23} \mathrm{H}_{33} \mathrm{~N}_{5} \mathrm{O}_{12}: 571.2$; found by $\operatorname{ESMS}(\mathrm{M}+\mathrm{H}): 572$.
ALTERNATE PROTOCOL 2

Protection of

Nucleosides for Oligonucleotide Synthesis

2.10.11

Supplement 16 
ALTERNATE PROTOCOL 3

Preparation of 5'-Silyl-2'Orthoester Ribonucleosides

2.10.12

4. Synthesize $N^{2}$-isobutyryl-5'-O-BzH-2'-O-ACE-guanosine as described (see Basic Protocol, steps 26 to 32). Elute the product (step 32) using 45:35:30 (v/v/v) hexane/EtOAc/acetone containing $0.5 \%$ (v/v) TEA.

The molecular weight of the product is $\left.959 \mathrm{~g} / \mathrm{mol} .{ }^{l} \mathrm{H} \mathrm{NMR}_{(\mathrm{CDCl}}\right): \delta 12.29(\mathrm{~b}, 1 \mathrm{H}), 10.04$ (b, $1 H), 7.96(s, 1 H), 7.31-7.12(m, 10 H), 5.96(d, J=5.2 \mathrm{~Hz}, 1 H), 5.90(s, 1 H), 5.22(s$, $1 H)$, 4.53-4.50 (m, $1 H), 4.36-4.30(\mathrm{~m}, 1 \mathrm{H}), 4.20-4.14(\mathrm{~m}, 1 \mathrm{H}), 4.10-4.06(\mathrm{~m}, 4 \mathrm{H})$, $3.82-3.80(\mathrm{~m}, 1 \mathrm{H}), 3.77-3.75(\mathrm{~m}, 1 \mathrm{H}), 3.68-3.61(\mathrm{~m}, 3 H), 3.52-3.50(\mathrm{~m}, 1 \mathrm{H}), 4.41-3.38$ $(\mathrm{m}, 1 \mathrm{H}), 2.83-2.78(\mathrm{~m}, 1 \mathrm{H}), 2.00(\mathrm{~s}, 3 \mathrm{H}), 1.99(\mathrm{~s}, 3 \mathrm{H}), 1.19(t, J=7.2 \mathrm{~Hz}, 6 \mathrm{H}), 0.01(\mathrm{~s}$, 9H), $0.00(\mathrm{~s}, 9 H) .{ }^{13} \mathrm{C} \mathrm{NMR}\left(\mathrm{CDCl}_{3}\right): \delta 179.8,171.3,171.0,155.9,148.6,148.1,143.9$, $143.8,137.3,128.24,128.23,127.2,126.32,126.29,121.0,112.4,86.2$, 84.8, 77.8, 76.9, 70.5, 63.15, 63.07, 62.9, 62.80 62.6, 36.0, 20.9, 20.8, 19.00, 18.98, 14.8, 14.7. Exact mass calculated for $\mathrm{C}_{42} \mathrm{H}_{61} \mathrm{~N}_{5} \mathrm{O}_{15} \mathrm{Si}_{3}$ : 959.4; found by $\operatorname{ESMS}(\mathrm{M}+\mathrm{H}): 960$.

5. Synthesize $N^{2}$-isobutyryl-5'-O-BzH-2'-O-ACE-3'-O-(N,N-diisopropylamino)methoxyphosphinyl guanosine as described (see Basic Protocol, steps 33 to 40). Elute the product (step 39) with 70:30 (v/v) hexane/acetone containing 0.5\% (v/v) TEA.

The product (Fig. 2.10.1) is a clear syrup, often pale yellow in color. The molecular weight is $1120 \mathrm{~g} / \mathrm{mol} .{ }^{1} \mathrm{H} \mathrm{NMR}\left(\mathrm{CDCl}_{3}\right.$, mixture of diasteromers $): \delta 12.06(\mathrm{~b}, 1 \mathrm{H}) ; 9.05$ and 8.97 (each as $b, 1 H) ; 8.00$ and 7.96 (each as $s, 1 H) ; 7.35-7.17(\mathrm{~m}, 10 \mathrm{H}) ; 6.09$ and 6.03 (each as $d, J=4.0 \mathrm{~Hz}, 1 \mathrm{H}$ ); 5.93 and 5.91 (each as $s, 1 H$ ); 5.39 and 5.26 (each as $s, 1 H$ ); $4.50-4.45(\mathrm{~m}, 2 \mathrm{H}) ; 4.24-4.11(\mathrm{~m}, 8 \mathrm{H}) ; 3.86-3.83(\mathrm{~m}, 2 \mathrm{H}) ; 3.76-3.56(\mathrm{~m}, 9 \mathrm{H}) ; 3.38$ and 3.34 (each as $d, J=12.0 \mathrm{~Hz}, 3 \mathrm{H}) ; 2.69-2.64(\mathrm{~m}, 1 \mathrm{H}) ; 2.07,2.06$, and 2.05 (each as $s, 6 H)$; 1.29-1.17 (m, 12H); 0.06, 0.04, 0.04, and 0.02 (each as $\mathrm{s}, 18 \mathrm{H}) .{ }^{31} \mathrm{P} \mathrm{NMR}\left(\mathrm{CDCl}_{3}\right.$, mixture of diasteromers): $\delta$ 152.0, 151.8. Exact mass calculated for $\mathrm{C}_{49} \mathrm{H}_{77} \mathrm{~N}_{6} \mathrm{O}_{16} \mathrm{PSi}_{3}$ : 1120.4; found by $\operatorname{ESMS}(M+H): 1121$.

\section{SYNTHESIS OF 2'-ACE-PROTECTED CYTIDINE RIBONUCLEOSIDE PHOSPHORAMIDITE}

The procedure for the synthesis of the $N^{4}$-acetyl-5'-O-silyl-2'-O-ACE-cytidine $3^{\prime}-O$ phosphoramidite is generally the same as for the uridine derivative (see Basic Protocol). The only significant changes occur in the solvent mixtures used for flash chromatographic purification of the various intermediates. Isolated yields per step are generally within $\pm 10 \%$ of the yields obtained for the uridine derivatives. The TLC conditions for the analysis of the crude reaction mixtures described in the Basic Protocol may be used for analysis in this protocol as well. Although the $R_{\mathrm{f}}$ values of the cytidine derivatives will differ slightly from those of the uridine derivatives, the differences between starting material and desired product will be similar at each step.

Additional Materials (also see Basic Protocol)

$N^{4}$-Acetylcytidine (285 g/mol; Monomer Sciences)

1. Synthesize $N^{4}$-acetyl-3', $5^{\prime}$-O $O$-TIPS-cytidine from $N^{4}$-acetylcytidine as described (see Basic Protocol, steps 1 to 12). For flash chromatography (steps 10 and 11), use a solvent system of 45:55 (v/v) hexane/EtOAc.

The product has an $R_{f}$ of 0.5 under these conditions. Its molecular weight is $527 \mathrm{~g} / \mathrm{mol} .{ }^{1} \mathrm{H}$ $\mathrm{NMR}\left(\mathrm{CDCl}_{3}\right.$, ): $\delta 10.63(\mathrm{~b}, 1 \mathrm{H}), 8.14(\mathrm{~d}, \mathrm{~J}=7.6 \mathrm{~Hz}, 1 \mathrm{H}), 7.35(\mathrm{~d}, \mathrm{~J}=7.6 \mathrm{~Hz}, 1 \mathrm{H}), 5.71$ $(s, 1 H), 4.19-4.13(m, 4 H), 3.92-3.80(m, 2 H), 2.21(s, 3 H), 0.99-0.79(m, 28 H) .{ }^{13} \mathrm{CNMR}$ $\left(\mathrm{CDCl}_{3}\right): \delta 171.6,163.4,155.0,144.2,96.7,91.5,81.8,75.0,63.3,59.8,24.8,17.4,17.3$, 17.23, 17.19, 16.9, 16.8, 16.7, 16.6, 13.3, 12.9, 12.8, 12.3. Exact mass calculated for $\mathrm{C}_{23} \mathrm{H}_{41} \mathrm{~N}_{3} \mathrm{O}_{7} \mathrm{Si}_{2}: 527.3$; found by $\operatorname{ESMS}(\mathrm{M}+\mathrm{H}): 528$. 
2. Synthesize $N^{4}$-acetyl-3', $5^{\prime}-O$-TIPS-2'-O-ACE-cytidine as described (see Basic Protocol, steps 13 to 19). Elute the product (step 19) using 46:50:4:0.5 (v/v/v/v) hexane/EtOAc/MeOH/TEMED.

Characterization data are not provided, because the crude product is directly carried to the next synthesis step.

3. Synthesize $N^{4}$-acetyl-2'-O-ACE-cytidine as described (see Basic Protocol, steps 20 to 25). Elute the product (step 25) using 67:30:3 (v/v/v) EtOAc/acetone/MeOH containing $0.5 \%(\mathrm{v} / \mathrm{v})$ TEMED.

The molecular weight of the product is $503 \mathrm{~g} / \mathrm{mol} .{ }^{1} \mathrm{H} \mathrm{NMR}\left(\mathrm{CDCl}_{3}\right): \delta 9.65(\mathrm{~b}, 1 \mathrm{H}), 8.27$ $(d, J=7.6 \mathrm{~Hz}, 1 \mathrm{H}), 7.41(\mathrm{~d}, \mathrm{~J}=7.2 \mathrm{~Hz}, 1 \mathrm{H}), 5.77(\mathrm{~d}, \mathrm{~J}=2.8 \mathrm{~Hz}, 1 \mathrm{H}), 5.60(\mathrm{~s}, 1 \mathrm{H}), 4.62-4.59$ $(\mathrm{m}, 1 \mathrm{H}), 4.38-4.36(\mathrm{~m}, \mathrm{lH}), 4.23-4.13(\mathrm{~m}, 5 \mathrm{H}), 4.03-3.98(\mathrm{~m}, 2 \mathrm{H}), 3.85-3.79(\mathrm{~m}, 5 \mathrm{H})$, $3.52(b, 1 H), 2.23(s, 3 H), 2.05(s, 3 H), 2.04(s, 3 H) .{ }^{13} C N M R\left(C D C l_{3}\right): \delta 171.2,171.16$, $163.1,155.6,146.8,112.9,97.1,92.4,85.3,68.6,63.25,63.17,63.10,62.9,60.8,25.1$, 21.1, 21.0. Exact mass calculated for $\mathrm{C}_{20} \mathrm{H}_{29} \mathrm{~N}_{3} \mathrm{O}_{12}: 503.2$; found by $\operatorname{ESMS}(M+\mathrm{H}): 504$.

4. Synthesize $N^{4}$-acetyl-5'-O-BzH-2'-O-ACE-cytidine as described (see Basic Protocol, steps 26 to 32). Elute the product (step 32) using 30:50:20 (v/v/v) hexane/EtOAc/acetone containing $0.5 \%$ (v/v) TEA.

The molecular weight of the product is $891 \mathrm{~g} / \mathrm{mol}^{1}{ }^{\mathrm{l}} \mathrm{HNMR}\left(\mathrm{CDCl}_{3}\right): \delta: 10.23(\mathrm{~b}, 1 \mathrm{H}), 8.30$ $(\delta, J=7.6 \mathrm{~Hz}, 1 \mathrm{H}), 7.36-7.14(\mathrm{~m}, 10 \mathrm{H}), 5.93-5.91(\mathrm{~m}, 2 \mathrm{H}), 5.67(\mathrm{~s}, 1 \mathrm{H}), 5.23(\mathrm{~s}, 1 \mathrm{H})$, 4.24-4.16 (m, 5H), 4.11-3.98 (m, 3H), 3.88-3.76 ( $\mathrm{m}, 5 \mathrm{H}), 3.01(\delta, J=8.0 \mathrm{~Hz}, 1 \mathrm{H}), 2.26$ $(s, 3 H), 2.03(s, 3 H), 2.02(s, 3 H), 0.07(s, 9 H), 0.05(s, 9 H) .{ }^{13} \mathrm{C} \mathrm{NMR}\left(\mathrm{CDCl}_{3}\right): \delta$ 171.0, 163.2, 155.0, 144.6, 143.91, 143.87, 128.3, 127.3, 126.35, 126.29, 112.8, 96.7, 89.4, 83.8, 78.5, 77.0, 67.2, 63.2, 63.1, 63.0, 62.9, 62.7, 60.6, 53.5, 24.9, 20.9, 20.8, 1.6. Exact mass calculated for $\mathrm{C}_{39} \mathrm{H}_{57} \mathrm{~N}_{3} \mathrm{O}_{15} \mathrm{Si}_{3}$ : 891.3; found by $\operatorname{ESMS}(\mathrm{M}+\mathrm{H}): 892$.

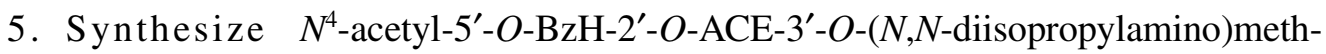
oxyphosphinyl cytidine as described (see Basic Protocol, steps 33 to 40). Elute the product (step 39) with 65:35 (v/v) hexane/acetone containing 0.5\% (v/v) TEA.

The product (Fig. 2.10.1) is a clear syrup, often pale yellow in color. The molecular weight is $1052 \mathrm{~g} / \mathrm{mol} .{ }^{1} \mathrm{H} \mathrm{NMR}\left(\mathrm{CDCl}_{3}\right.$, mixture of diasteromers): $\delta 8.77(\mathrm{~b}, \mathrm{lH}) ; 8.36$ and 8.34 (each as $d, J=4.8 \mathrm{~Hz}, 1 \mathrm{H}) ; 7.36-7.15(\mathrm{~m}, 10 \mathrm{H}) ; 6.00(\mathrm{~d}, \mathrm{~J}=6.8 \mathrm{~Hz}, 1 \mathrm{H}) ; 5.94(d, J=4.8$ $\mathrm{Hz}, 1 \mathrm{H}) ; 5.81$ and $5.76($ each as $\mathrm{s}, 1 \mathrm{H}) ; 4.30-4.15(\mathrm{~m}, 8 \mathrm{H}) ; 4.10-4.02(\mathrm{~m}, 1 \mathrm{H}) ; 3.96-3.77$ $(\mathrm{m}, 5 \mathrm{H}) ; 3.60-3.52(\mathrm{~m}, 3 \mathrm{H}) ; 3.34$ and 3.31 (each as $d, \mathrm{~J}=12.0 \mathrm{~Hz}, 3 \mathrm{H}) ; 2.23(\mathrm{~s}, 3 \mathrm{H}) ; 2.05$, 2.05, and 2.04 (each as $s, 6 H$ ); 1.20-1.13 (m, 12H); 0.08, 0.07, 0.06, and 0.04 (each as s, $18 \mathrm{H}) .{ }^{31} \mathrm{P} \mathrm{NMR}\left(\mathrm{CDCl}_{3}\right.$, mixture of diasteromers $): \delta 152.2,151.4$. Exact mass calculated for $\mathrm{C}_{46} \mathrm{H}_{73} \mathrm{~N}_{4} \mathrm{O}_{16} \mathrm{PSi}_{3}:$ 1052.4; found by $\operatorname{ESMS}(\mathrm{M}+\mathrm{H}): 1053$.

\section{COMMENTARY}

\section{Background Information}

Until recently, most advancements in oligonucleotide synthesis technologies focused on DNA. One reason for this "DNA-centricity" is that DNA is easier to work with than RNA, making advancements in DNA technologies easier to develop. Another, more important, reason is that biologists have traditionally attributed DNA with far more therapeutic significance than RNA. As a result, the market for synthetic RNA has traditionally been small and highly specialized.

The recent discovery that small interfering RNAs (siRNAs) induce gene suppression in mammalian cells (Elbashir et al., 2001) has, however, sparked tremendous interest in developing siRNA-based assays and high-throughput screens to identify and study disease targets. Reliable, efficient, and high-quality RNA synthesis methods are now critically important for enabling cutting-edge research in drug discovery and therapeutic intervention. As a result, a substantial and rapidly growing market for synthetic RNA has been created.

Three methods for chemically synthesizing siRNAs are now well established: $2^{\prime}$-TBDMS, 2'-TOM, and 2'-ACE. 2'-O-tert-Butyldimethylsilyl (TBDMS) chemistry was originally developed in the 1980s, when Ogilvie and Usman applied a 2'-TBDMS strategy for 2'-hy-
Protection of Nucleosides for Oligonucleotide Synthesis

2.10 .13 
droxyl protection (Usman et al., 1987) to classical phosphoramidite-based DNA synthesis (Caruthers, 1987; also see UNIT 2.5). The more recently developed 2'-O-triisopropylsilyloxymethyl (TOM) 2'-hydroxyl chemistry implements a $2^{\prime}$-silyl protecting group to achieve improved synthesis efficiencies relative to $2^{\prime}$ TBDMS (Wu and Pitsch, 1998; also see UNIT 2.9). 2'-TOM chemistry is still limited, however, by such factors as oligonucleotide length and yield.

Significant improvements in RNA synthesis were achieved with the $5^{\prime}$-silyl-2'-acetoxyethoxy (ACE) chemistry (Scaringe et al., 1998) described in this unit. For synthetic RNA to be useful to biological practitioners studying gene function, it has to meet certain physical, quality, and convenience criteria. Some of the characteristics of synthetic RNA that are important to the user are:

1. Sequence integrity: assurance that the sequence desired is actually the one produced.

2. Scalability: the ability to obtain large quantities of RNA for use in high-throughput screens or animal models.

3. Strand length: the ability to obtain long strands of RNA (e.g., to make hairpin structures).

4. Chemical modifications: the ability to obtain RNA featuring chemical labels or preservatives (e.g., to improve pharmacokinetics in animal tissues).

5. Robustness: the ability of the RNA protecting groups to repel nucleases, facilitating handling and long-term storage.

6. Labor intensiveness: the ease of deprotecting, annealing, purifying, and/or preparing the RNA for use in a biological assay.

7. Short- and long-term cost: as measured in both time and money.

2 -ACE chemistry is the only method capable of meeting all of the criteria listed above. First, 2'-ACE chemistry provides superior sequence integrity; $99 \%$ efficiencies for 21-mers are routinely achieved at coupling speeds as fast as 2 nucleotides/min. By comparison, $2^{\prime}-\mathrm{TOM}$ chemistry achieves $99 \%$ efficiency when one nucleotide is coupled every 2 to $6 \mathrm{~min}$. Second, $2^{\prime}$-ACE chemistry delivers a crude product of high purity. 2 -ACE chemistry produces milligram to kilogram quantities of $>90 \%$ pure material for high-throughput or in vivo efforts in less time, and at a lower cost, than any other method. Third, 2'-ACE is the only chemical method that can be used to economically synthesize long double-stranded RNA (dsRNA) or siRNA hairpins $>30$ bases in length; oligori- bonucleotides of up to 80 bases can be synthesized at efficiencies of $\sim 60 \%$, far greater than for any other method. By comparison, 2'-TOM chemistry achieves $36 \%$ efficiencies for synthesis of 50-mers. Fourth, the 2'-ACE protecting scheme enables virtually any chemical modification to be easily incorporated into the oligoribonucleotide. For in vivo applications, such chemical modifications are required to increase RNA stability in tissues and fluids. The $2^{\prime}$-TBDMS and 2'-TOM methods are more restricted in the type and number of modifications that can be added. Fifth, 2'-ACE-protected RNA provides superior handling properties relative to other methods. As with other protecting strategies, the 2 -ACE group renders the oligoribonucleotide resistant to nuclease and other forms of degradation during handling and purification. 2'-ACE chemistry is the only method, however, in which the last deprotection step can be carried out in a mild, aqueous solution. This step is typically done using 100 $\mathrm{mM}$ acetic acid, $\mathrm{pH} 3.8$ (conditions under which the RNA is quite stable) and takes only $30 \mathrm{~min}$ to complete. Finally, when considering cost, 2'-ACE chemistry provides better economies of scale than the other methods. For smallscale production runs, $2^{\prime}$-ACE is slightly more expensive than 2'-TBDMS and 2'-TOM; however, when larger-scale production runs are required, fast coupling times and high coupling efficiencies ensure that $2^{\prime}$-ACE chemistry is cheaper than competing technologies.

\section{Critical Parameters and Troubleshooting}

For all of these protocols, anhydrous reaction conditions must be maintained. Traces of water will severely affect the yield and purity of the product at each step. Solvents should be stored over molecular sieves or should be freshly distilled from an appropriate drying agent. All glassware must be thoroughly cleaned and dried in an oven for $30 \mathrm{~min}$ at $110^{\circ}$ to $120^{\circ} \mathrm{C}$ prior to use.

Thin-layer chromatography (TLC) on silica gel is conveniently used throughout these protocols to monitor the progress of the various reactions. It is also used to provide a rapid initial assessment of the purity of the chromatographically isolated products. The absolute purity of the product compounds, however, should be determined by NMR spectroscopy $\left({ }^{1} \mathrm{H},{ }^{13} \mathrm{C}\right.$, or ${ }^{31} \mathrm{P}$, where appropriate) and/or mass spectrometry.

During the synthesis of $3^{\prime}, 5^{\prime}-O$-TIPS-2'-OACE-nucleosides from $3^{\prime}, 5^{\prime}$-O-TIPS-nucleo- 
sides (e.g., S.3; see Basic Protocol, steps 13 to 19), an additional aliquot of pyridinium $p$-toluenesulfonate (up to 1.0 equiv total) can be added to complete the reaction. If additional pyridinium $p$-toluenesulfonate is added, however, additional TEMED (up to 2.5 equiv) must be added to compensate. This reaction typically takes 36 to $48 \mathrm{hr}$ to complete at room temperature, but it can be accelerated by gently refluxing at $38^{\circ}$ to $40^{\circ} \mathrm{C}$. The solution should eventually appear clear, with a slight yellow or orange color. When analyzing the progress of this reaction with TLC, beware that 4-tertbutyldimethylsiloxy-3-penten-2-one is UV absorbing and volatile. It appears on the TLC plate as a dark spot or pair of spots (two isomers) migrating at the solvent front. Upon standing, the spots will slowly disappear.

When preparing a silica gel flash chromatography column to purify the desired product (see Basic Protocol, step 18), only use TEMED as the base. Do not use TEA or another tertiary amine. TEMED-HF is used to deprotect the $5^{\prime}$ and $3^{\prime}$-hydroxyls in the next step. If TEA is present in that step, the HF salt of TEA will be generated. The TEA-HF salt migrates on silica gel and is difficult or impossible to separate from the 2'-O-ACE nucleoside product. This problem does not occur with the more polar TEMED-HF salt. When eluting, it is very important to remove the several small impurities that elute just ahead of the desired product. If present, they severely complicate subsequent purifications. Therefore, when the product begins to elute, collect smaller fractions and analyze carefully by TLC.

During the synthesis of 2 -ACE-nucleosides from 3',5'-O-TIPS-2'-O-ACE-nucleosides (see Basic Protocol, steps 20 to 25), it is important to take care when loading the silica gel flash chromatography column. If the product is not loaded slowly, heat can be generated, which may disrupt the silica gel bed.

During the synthesis of $5^{\prime}-O-\mathrm{BzH}-2^{\prime}-O$ ACE-nucleosides from 2'-O-ACE-nucleosides (see Basic Protocol, steps 26 to 32), it is important to add the diisopropylamine-activated silylating reagent slowly to the nucleoside solution. Begin by adding 0.5 equiv of the silylating reagent, and then taper to smaller aliquots as the reaction proceeds to completion. It is best to do this reaction steadily, over a period of 10 to $15 \mathrm{~min}$, without pausing for an extended time between additions of silyl reagent. The silylating reagent appears to react somewhat with the nucleobases on uridine and guanosine, requiring more than 1.0 equiv to $5^{\prime}$-protect all of the starting material. As soon as TLC shows that the reaction is complete, immediate work-up of the reaction is required.

At the end of the final synthesis step, yielding $5^{\prime}$ - $O$-BzH-2'-O-ACE-3'- $O$-( $N, N$-diisopropylamino)methoxyphosphinyl nucleosides from $5^{\prime}-O$-BzH-2'-O-ACE-nucleosides, elute the final product from the chromatography column, and then co-evaporate the pooled fractions with toluene to ensure the amidite is not concentrated down into TEA. Finish with one or two co-evaporations using acetonitrile on high vacuum.

\section{Anticipated Results}

The isolated yields presented in the protocols represent typical values obtained. The quality of the reagents and the dryness of the solvents will have a significant impact on product yield and purity, as will the amount of care taken during the chromatographic purifications. The product yields are explicitly given at each step for uridine in the Basic Protocol. These values are also representative of the yields obtained for the corresponding adenosine, guanosine, and cytidine derivatives, within about $\pm 10 \%$. The TIPS-protected nucleosides obtained in the first step of the synthetic scheme (S.2) are generally white solids; all other products are generally viscous syrups, often pale yellow in color.

It is possible to analyze all products by reversed-phase high-performance liquid chromatography (RP-HPLC). Typical conditions are as follows: analytical C18 column (available from a variety of vendors); linear gradient of HPLC-grade acetonitrile in aqueous $0.05 \mathrm{M}$ ammonium acetate, $\mathrm{pH} 8.5$; and UV detector monitoring at $260 \mathrm{~nm}$. Typical HPLC analytical data for the final phosphoramidites (Waters NovaPak C18 column, $3.9 \times 150-m m$ plus guard cartridge; flow rate, $1 \mathrm{~mL} / \mathrm{min}$; linear gradient from $25 \%$ to $100 \%$ [v/v] acetonitrile over $30 \mathrm{~min}$ ): retention times of 33 to $35 \mathrm{~min}$; purities $\geq 97 \%$ (by integration of all peaks in the 260-nm chromatogram); $\leq 0.1 \%$ desilylated material (retention times of 16 to $18 \mathrm{~min}$ ); $\leq 1 \%$ hydrolyzed material (retention times of 25 to $27 \mathrm{~min}$ ).

All methods described in this unit can be scaled up to yield $\sim 300 \mathrm{mmol}(\sim 300 \mathrm{~g})$ of phosphoramidites simply by linearly increasing the amounts of all materials used in the procedures. The protected phosphoramidite monomers prepared using these methods are ideal for solid-phase RNA oligonucleotide synthesis.
Protection of Nucleosides for Oligonucleotide Synthesis

2.10.15

Supplement 16 


\section{Time Considerations}

Chemical synthesis of 2'-ACE-protected phosphoramidites is an involved process that, from start to finish, takes experienced chemists days to weeks to complete. The following time estimates include reagent preparation, labor, reaction, evaporation, purification, and drying, and assume that all reactions proceed smoothly. Synthesis of 3',5'-O-(tetraisopropyldisiloxane1,3-diyl)uridine from uridine (steps 1 to 12 of the Basic Protocol) takes $\sim 2$ days. Synthesis of 3',5'-O-(tetraisopropyldisiloxane-1,3-diyl)-2'$O$-ACE-uridine (steps 13 to 19 ) takes $\sim 3$ days. Synthesis of 2'-O-ACE-uridine (steps 20 to 25) and synthesis of $5^{\prime}-O$-BzH-2'-O-ACE-uridine (steps 26 to 32) each take 1 day. Synthesis of $5^{\prime}$ - $O$-BzH-2'-O-ACE-3'-O-( $N, N$-diisopropylamino)methoxyphosphinyl uridine (steps 33 to 40 ) takes $\sim 2$ days. As such, synthesis of $2^{\prime}-O$ ACE-protected uridine ribonucleoside phosphoramidites takes $\sim 9$ days in total. Times for Alternate Protocols 1 to 3 are similar.

\section{Literature Cited}

Caruthers, M.H. 1985. Gene synthesis machines: DNA chemistry and its uses. Science 230:281285.
Elbashir, S.M., Harborth, J., Lendeckel, W., Yalcin, A., Weber, K., and Tuschl, T. 2001. Duplexes of 21-nucleotide RNAs mediate RNA interference in cultured mammalian cells. Nature 411:494498.

Matteucci, M.D. and Caruthers, M.H. 1981. Synthesis of deoxyoligonucleotides on a polymer support. J. Am. Chem. Soc. 103:3185-3191.

Scaringe, S.A., Wincott, F.E., and Caruthers, M.H. 1998. Novel RNA synthesis method using 5'silyl-2'-orthoester protecting groups. J. Am. Chem. Soc. 120:11820-11821.

Usman, N.O., Ogilvie, K.K., Jiang, M.Y., and Cedergren, R.J. 1987. The automated chemical synthesis of long oligoribonucleotides using $2^{\prime}-O$ silylated ribonucleoside $3^{\prime}$ - $O$-phosphoramidites on a controlled-pore glass support: Synthesis of a 43-nucleotide sequence similar to the $3^{\prime}$-half molecule of an Escherichia coli formylmethionine tRNA. J. Am. Chem. Soc. 109:7845-7854.

Wu, X. and Pitsch, S. 1998. Synthesis and pairing properties of oligoribonucleotide analogues containing a metal-binding site attached to $\beta$-D-allofuranosyl cytosine. Nucl. Acids Res. 26:43154323.

Contributed by Stephen A. Scaringe,

David Kitchen, Robert J. Kaiser, and William S. Marshall

Dharmacon Inc.

Lafayette, Colorado
Preparation of 5'-Silyl-2'Orthoester Ribonucleosides 2.10.16 